\title{
The role of cognitive assessments and epistemological beliefs in Predicting students' academic engagement
}

\author{
Akbar Rezaei ${ }^{1}$, Jafar Bahadorikhosroshahi ${ }^{2}$ \\ 1-Associate Professor, Department of Psychology, Payame Noor University (PNU), Tehran, Iran \\ (Corresponding Author). ORCID: 0000-0003-3349-2163 E-mail: Akbar_rezaei@pnu.ac.ir \\ 2- Ph.D. Student in Educational Psychology, Department of Education, Faculty of Education and Psychology, \\ Azarbaijan Shahid Madani University, Tabriz, Iran. ORCID: 0000-0002-9448-934X
}

Received: $10 / 02 / 2019$

Accepted: 04/05/2019

\begin{abstract}
Introduction: Academic engagement is a multidimensional construct, that they are involved in which cognitive factors, including cognitive assessments and epistemological beliefs.

Aim: The purpose of this study was to evaluate the role of cognitive assessments and epistemological beliefs in predicting academic engagement of students.

Method: The research method was determining the role of cognitive assessments and epistemological beliefs in predicting academic engagement students. The statistical population of this study consisted of all were students of Payame Noor University of Tabriz in the academic year of 2017-2018. The population of this study was 400 students were select through cluster sampling. The data were collected through questionnaires of academic engagement, cognitive assessment and epistemological beliefs. Data analysis was performed by Pearson correlation coefficient and multiple regression analysis.

Results: The results of this study showed that there is a positive and significant relationship between the components of cognitive assessments, self-efficacy, internal evaluation and epistemological beliefs about the certainty of knowledge with academic engagement. On the other hand, there is a negative and significant relationship between the speed of learning and the intrinsic nature of epistemological beliefs with academic engagement. Also, the results of regression analysis showed that cognitive assessment and epistemological beliefs can predict the variables of academic involvement in students.
\end{abstract}

Conclusion: Attention to cognitive assessment and epistemological beliefs play an important role in academic engagement.

Keywords: Academic engagement, Cognitive assessment, Epistemological beliefs

\footnotetext{
How to cite this article : Rezaei A, Bahadorikhosroshahi J. The role of cognitive assessments and epistemological beliefs in predicting students' academic engagement .Shenakht Journal of Psychology and Psychiatry. 2019; 6 (3): 59-70 .URL: http://shenakht.muk.ac.ir/article1-642-fa.pdf

Copyright (C) 2018 the Author (s). Published by Kurdistan University of Medical Sciences. This is an open access article distributed under the terms of the Creative Commons Attribution-Non Commercial License 4.0 (CCBY-NC), where it is permissible to download, share, remix, transform, and buildup the work provided it is properly cited. The work cannot be used commercially without permission from the journal.
} 


\section{نقش ارزيابىهاى شناختى و باور هاى معرفتشناختى در ييشبينى دركيرى تحصيلى دانشجويان}

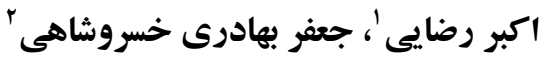

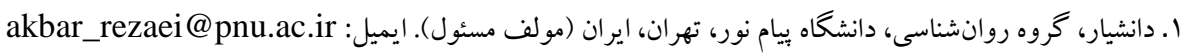

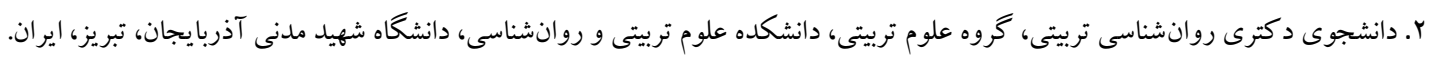

مقدمه: درگيرى تحصيلى سازهاى جِندبعدى است كه عوامل شناختى از جمله ارزيابىهاى شناختى و باورهاى معرفتشناختى در

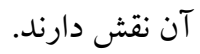

هدف: هدف يُوهش حاضر نقش ارزيابى هاى شناختى و باورهاى معرفتشناختى در ييشبينى در گيرى تحصيلى دانشجويان بود. روش: روش يُزوهش توصيفى از نوع همبستخى بود. جامعه آمارى اين يثزوهش شامل كليه دانشجويان دانشكاه بيام نور مركز تبريز

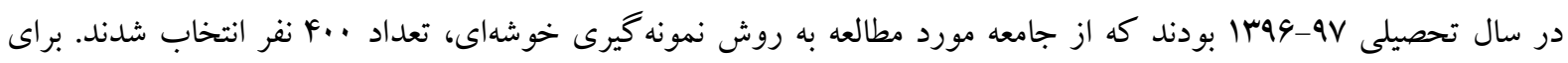

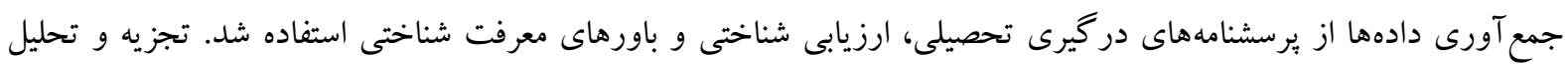

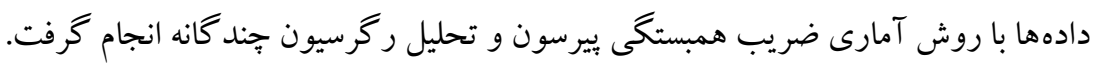
يافتهها: نتايج يزوهش نشان داد كه بين مؤلفهاى ارزيابى شناختى خود كار آمدى، ارزش گذارى درونى و باورهاى معرفت-

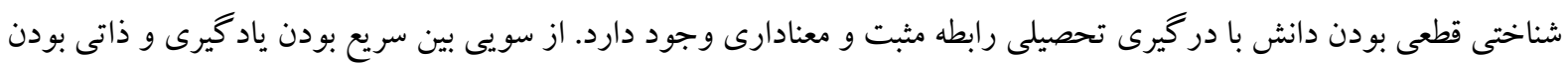

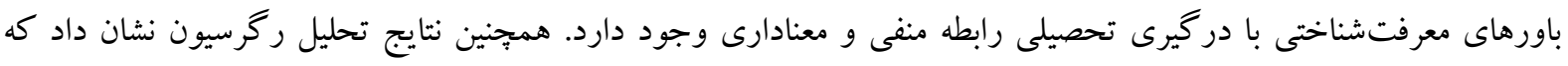

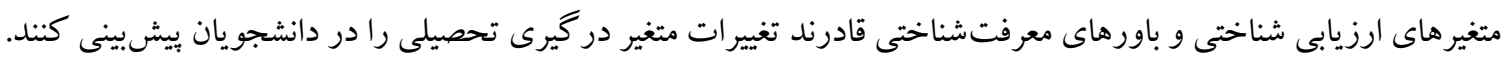
نتيجه گيرى: بنابر اين توجه به ارزيابى شناختى و باورهاى معرفتشناختى نقش مهمى در در گيرى تحصيلى دارند. كليدوازهها: در گيرى تحصيلى، ارزيابى شناختى، باورهاى معرفتشناختى

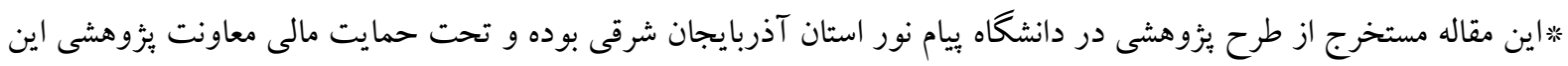
دانشگاه قرار كرفته است. 
تاكنون يُزوهشهايى در سازمانهاى آموزشى انجام

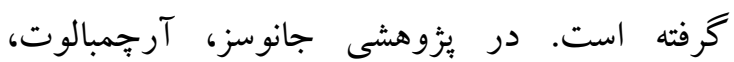

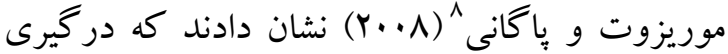
تحصيلى ارتباط نزديكى با عوامل دانشگاهى دارد، به به به

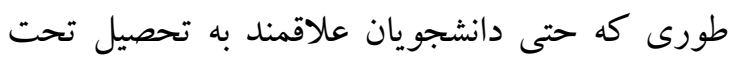
تأثير عوامل منفى دانشخاهى تركى تحصيل مى كنند. يززوهشهاى ديخرى نشان داده است كه بين مؤلفههاى روانشناختى خود كار آمدى با دركيرى تحصيلى رابطه ى مستقيم وجود دارد (كريستن، كارولاين، وندى و

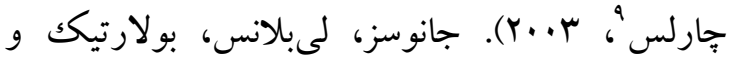

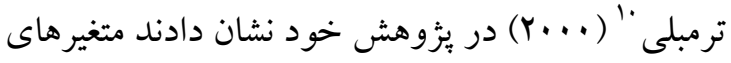
مربوط به تجربههاى تحصيلى بهترين بيشيينى كننده براى بر آورد ميزان بيشرفت تحصيلى است. يكى از متغيرهايى كه ارتباط با درگيرى تحصيلى دارد، متغير ارزيابى شناختى است. ارزيابى شناختى سطوح بالاى فعاليتهاى فراشناختى را مورد توجه قرار مى دهد. راهبردهاى ياد شده شامل جندين راهبرد است كه

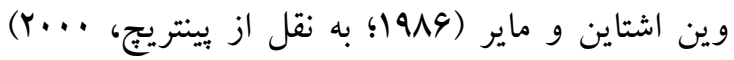
آنها را شامل يادآورى، بسط و سازماندهى مى واند. اين راهبردها با عملكرد تحصيلى رابطه دارند و مىتوان

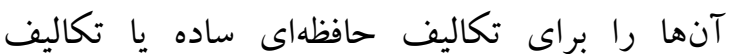
ييجيدهترى كه مستلزم دركك متن است به كار برد

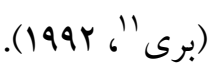

راهبردهاى يادآورى شامل از بر خوانى جملات براى

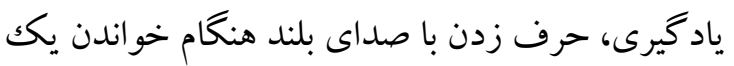
متن، برجسته كردن و خط كشى زير مطالب مهم با روش نسبتاً فعال و نه سطحى است. فرض مىشود كه راهبردهاى ياد آورى به دانش آموزان كمكك مى كنند تا توجهشان را متمركز كنند و اطلاعات مهم را از

\footnotetext{
${ }^{8}$. Janosz, Archambault, Morizot \& Pagani

${ }^{9}$. Kirsten, Carolyn, Wendy \& Charles

${ }^{10}$. Le Blancc, Boulertice \& Tremblay

11. Berry
}

امروزه نظامهاى آموزشى، با تغيير و تحولات زيادى روبرو هستند كه در اين ميان دانشگاهها، سعى دارند آموزشهاى خود را مطابق با نيازهاى دانشجويان و

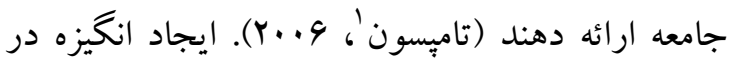
دانشجويان به طورى كه بتواند در تحصيلات موفق باشند، يكى از جالشهاى مهم در زمينه ارتقاى كيفيت

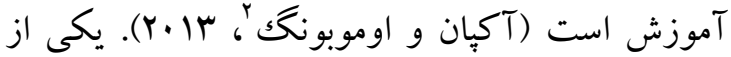
مهمترين شاخصهاى نشان دهندهى كيفيت آموزش، درگيرى تحصيلى 'دانشجويان است (ونيودن، ريتزن و

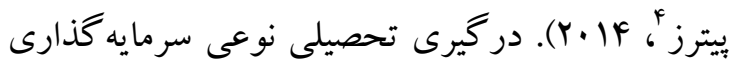
روانشناختى و تلاش مستقيم براى ياد گيرى، فهميدن و تسلط در دانش و مهارتهاى مورد نياز است (صيامى،

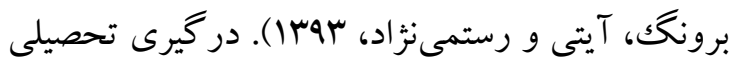
دربر گيرنده ابعاد رفتارى، عاطفى و شناختى است

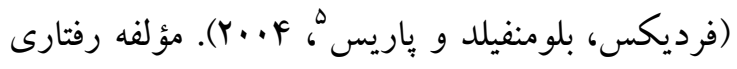
درگيرى تحصيلى، به رفتارهاى قابل مشاهده تحصيلى

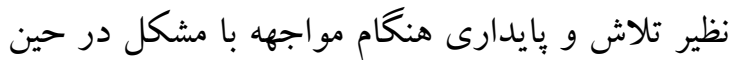
انجام تكاليف درسى و تقاضاى كمكك از اساتيد يا همسالان به منظور يادگيرى و درك مطالب درسى

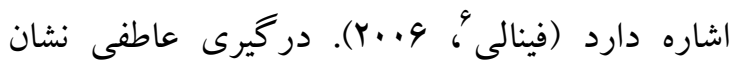
دهنده واكنشهاى عاطفى، علاقه و ارزش نهادن به فعاليت هاى دانشگاه است و داراى نشانگرهاى (اعلاقه)، "ارزش) و (عاطفه)) است. درگيرى شناختى شامل انواع فرايندهاى يردازش است كه دانشآموزان جهت

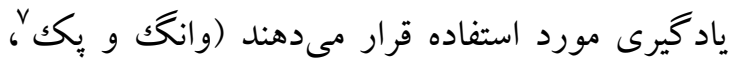
.$(r \cdot 1)$ درگيرى تحصيلى به عنوان يك متغير، به حوزه مطالعات تعليم و تربيت راه يافته است و در اين زمينه

\footnotetext{
1. Thompson

2. Akpan \& Umobong

3 . academic engagement

4. Van Uden, Ritzen \& Pieters

5 . Fredricks, Blumenfeild \& Paris

6 . Finlay

. Wang \& Peck
} 
بيش مستقل و با استفاده از برسش نامه مورد بررسى

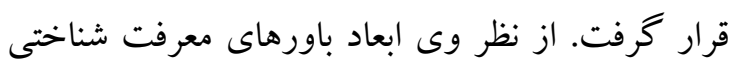

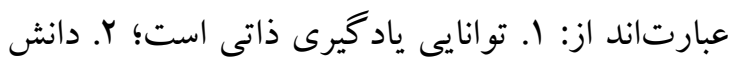

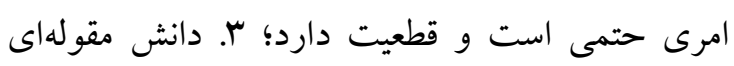

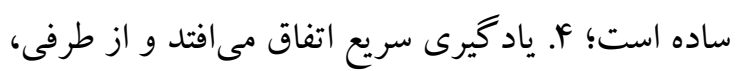
تحقيقات آموزشى نشان مىدهند كه باورهاى معرفت شناختى بر رويكردهاى يادگيرى و نتايج ياد گيرىهاى ذهنى تأثير كذار است.

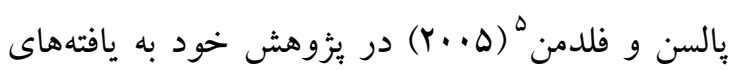

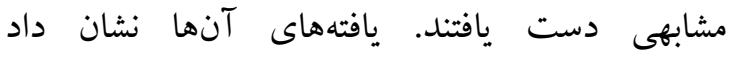
دانشجويانى كه بيشتر داراى اين باور خام و سادهلوحانه بودند كه توانايى يادگيرى ثابت است، كمتر احتمال

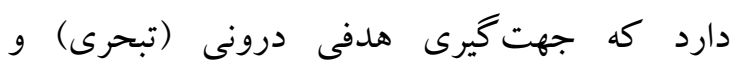
جهت گيرى هدفى بيرونى (عملكردى) داشته باشند. همجنين دانشجويانى كه بيشتر داراى اين باور خام و سادهلوحانه بودند كه ساختار دانش ساده است، يعنى از جنبههاى به شكل تكهها و قطعههاى مجزاى اطلاعات تشكيل يافته است (دانش ساده) كمتر احتمال دارد جهت گيرى هدفى درونى داشته باشند. همجِينين

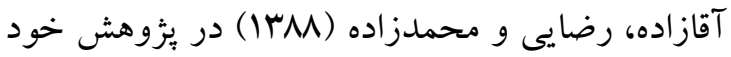
نشان دادند كه دركيرى شناختى با متغيرهاى خود كار آمدى، جهت گيرى هدفى تسلطى، عملكردى و قطعيت دانش همبستكى مثبت معنادار؛ ولى با جهت كيرى هدفى بيرونى، يادگيرى سريع و توانايى ذاتى

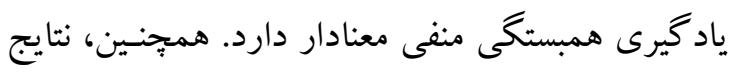

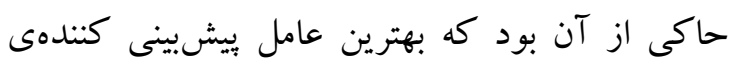

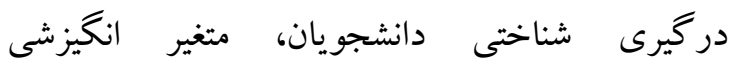
خودكار آمدى است و متغيرهاى جهت گيرى هدفى داحى تسلطى، قطعيت دانش، جنسيت (مؤنث بودن) و توانايى ذاتى يادگيرى در ردههاى بعدى قرار دارند. البته

5. Paulsen \& Feldman
فهرستها يا متون انتخاب كنند و اين اطلاعات را فعالانه در حافظه كارى خود قرار دهند، با اين وجود راهبردهاى ياد شده، نشان دهنده سطح يردازش جندان عميقى نيستند. راهبردهاى بسط شامل تبين، تفسير و

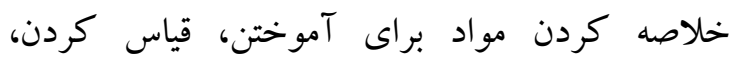
يادداشتبردارى خلاقانه و ياسخدهى است (وينستون و

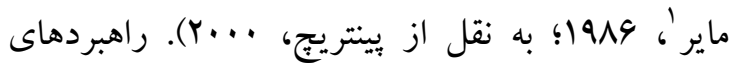
مذكور سطح يادگيرى عميقترى را نشان مىدهند و مستلزم آن هستند كه يادگيرنده از سطح متن مطالعه شده فراتر رود و دست به استباط در آن مورد بزند. نوع ديخرى از راهبردهاى يردازش عميق، سازماندهى است كه شامل رفتارهايى همجيون انتخاب ايده اصلى رهي متن، خط كشى، برجسته كردن متن يا مواد براى آموختن، استفاده از فنون مختلف براى انتخاب و و

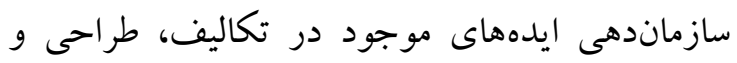

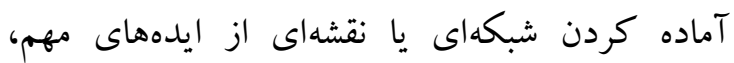
شناسايى ساختارهاى نثر يا توضيح و تفسير متن است. راهبردهاى سازماندهى باعث دركى عميقتر مواد مىشوند و اكثر يادگيرندگان موفق و حرفهاى از اين

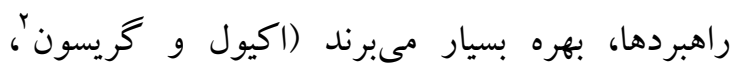
. (Y.人 اخيراً برخى بثزوهش ها رابطه ميان باورهاى معرفت شناختى با اهداف ييشرفت را مورد بررسى قرار دادهاند.

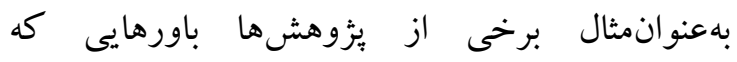
دانشجويان درباره دانش و دانستن دارند (باورهاى

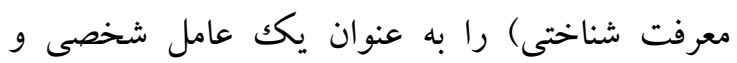
يشايند بسيار مهم براى درگيرى تحصيلى مورد توجه

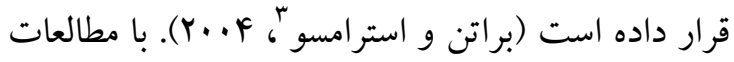

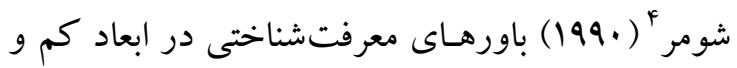

\footnotetext{
Veniston \& Maye

. Akyol \& Garrison

. Braten \& Stromso

. Shomer
} 
شدند. به اين صورت كه در اولين مرحله از بين رشته-

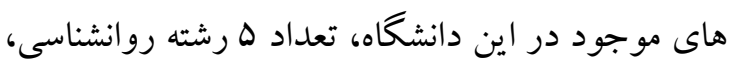
زبان انگليسى، فيزيك، علوم اجتماعى و زيستشناسى به صورت تصادفى انتخاب شدند و سبِ از بين رشته هاى انتخاب شده از هر كدام تعداد دو كلاس درس به به به بـ صورت تصادفى انتخاب شده و مورد بررسى قرار

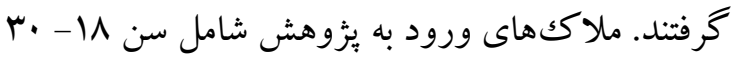
سال، دانشجو بودن و دانشجوى دانشگاه ييام نور تبريز بود و ملاكك هاى خروج شامل عدم تطابق سنى با دامنه سنى، عدم دانشجو بودن در دانشگاه ييام نور مركز تبريز و تكميل ناقص برسشنامهها بود.

ابزار براى گردآورى دادهها از يرسشنامهاى زير استفاده

يرسشنامه دركيرى تحصيلح: اين برسشنامه توسط

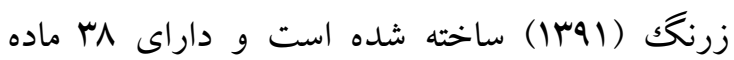
است. هر ماده داراى ينج گزينه در طيف ليكرت است. شيوهاى نمرهدهى به گونهاى است كه براى كزئ خزينه

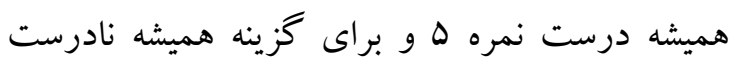
نمره ا در نظر گرفته شده است. بايايى اين ابزار در

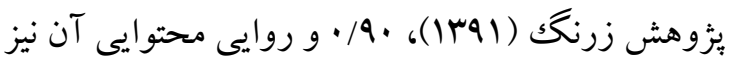
به شيوه داورى تخصصى مورد سنجش قرار گرفت كه

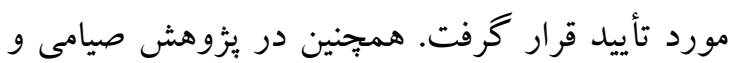
همكاران (rar|) ضريب پايايى يرسشنامه به روش آلفاى كرونباخ 9V/ • گز ارش كرديد. يرسشنامه ارزيابى شناختى: در اين وثروهش، ارزيابى

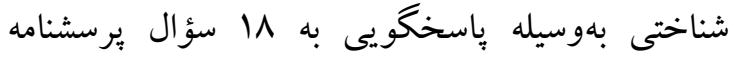

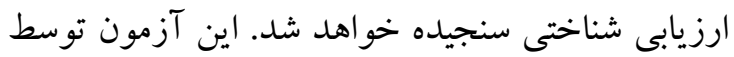

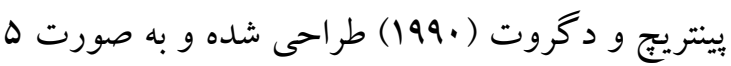
درجهاى ليكرت نمره گذارى مىشود. مدل برازش بهترى با دادهها داشته و با مدل نظرى هم هماهنگى
توانايى ذاتى يادگيرى با درگيرى شناختى همبستخى منفى داشت و نقش اش بازدارنده بود. در كل يُزوهشهاى مورد بحث، اهميّت ارتباط باورهاى معرفتشناختى را در فهم درگيرى تحصيلى بردي دانشجويان نشان مىدهند و مطالعه يِيشينه يزوهشى مشخص كرد كه يزوهشهاى كمترى در زمينه ارزيابىهاى شناختى با در گيرى تحصيلى انجام شده

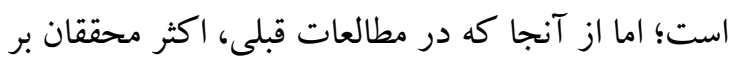
يكك يا دو متغير متمركز بودهاند و مؤلفههاى متغيرهاى باورهاى معرفتشناختى و ارزيابىهاى شناختى بر درگيرى تحصيلى را بررسى نكردهاند كه با بررسى باتى

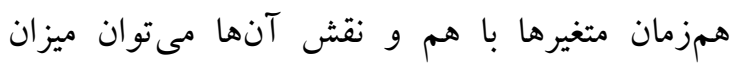
كار آمدى نسبى آنها را در بش بينى در گيرى تحصيلى برآورد كرد كه در يُزوهش حاضر به اين امر برداخته

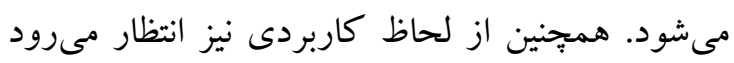

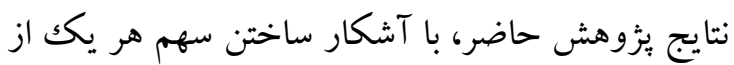
اين متغيرها و مؤلفههاى آنها، اطلاعاتى مفيد در اختيار

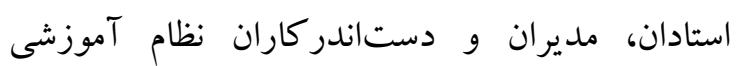
دانشگاهها قرار دهد تا آنها بتواند شرايط و موقعيت بهترى براى موفقيت تحصيلى دانشجويان فراهم آورند. بنابراين بر اين اساس هدف يزوهش حاضر، نقش ارزيابىهاى شناختى و باورهاى معرفتشناختى در بر بر ييشبينى در گيرى تحصيلى دانشجويان بود.

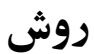
اين يزوهش از نظر هدف كاربردى و از نظر روش

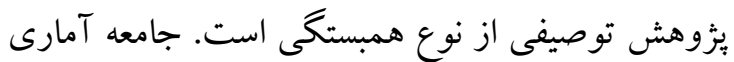
اين يُزوهش شامل كليه دانشجويان دانشگاه بيام نور مركز تبريز در سال تحصيلى به نوع يزووهش و تعداد متغيرهاى مورد مطالعه از جامعه برئ

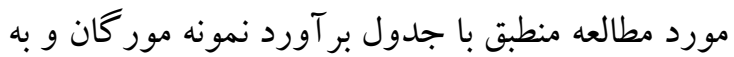
روش نمونه گيرى خوشهاى تعداد .. F نفر انتخاب 
يرسشنامهاى اين يُزوهش كه حاوى نكات لازم در

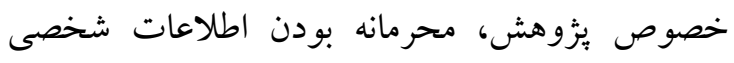
آزمودنىها و مشخصات فردى بود به تعداد مورد نياز

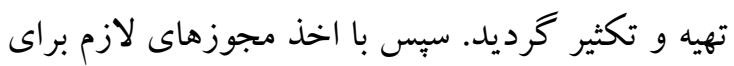
اجراى يثزوهش به همراه احتساب حجم نمونه، يرسشنامه در بين دانشجويان توزيع گرديد. در نهايت براى تجزيه و تحليل دادهها از شاخصهاى توصيفى

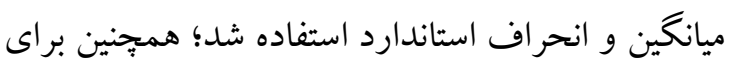
تحليل فرضيه هاى بزٔوهشى از ضريب همبستكى بيرسون و تحليل رگرسيون استفاده شد.

\section{يافتهها}

شاخصهاى براكندگى و تمايل مركزى متغيرهاى يزوهش در جدول | نشان داده شده است.
بيشترى دارد. نسبت خى دو اين آزمون برابر با TF/9

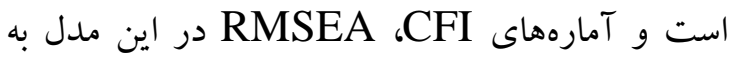

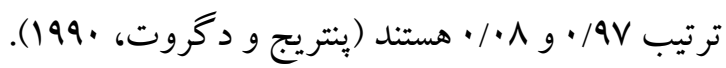
يرسشنامه باورهاى معرفت شناختى: برسشنامه اوليه توسط شومر در سال .199 طراحى و توسط شراو، بنديكس و دانكل (Y... (Y) تجديد نظر شده است. در اين :ثزوهش، از برسشنامه تجديد نظر شده آن استفاده

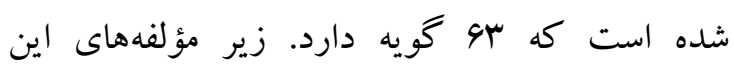
برسشنامه شامل دانش ساده، دانش قطعى، دانش ذاتى،

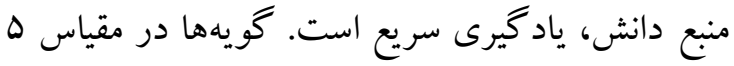
درجهاى ليكرت از (1 كاملاً مخالف) تا هـ (كاملاً موافق) درجه بندى شدهاند. سيف (سوسا) در يزوهش خود ضريب آلفاى كرونباخ را براى اين ابعاد بين 191. تا تا مF/ • به دست آوردهاند.

\begin{tabular}{|c|c|c|}
\hline خطاى استاندارد ميانكين & ميانكين (انحر اف استاندارد) & كروهاها \\
\hline$\cdot / r V$ & $(V / \Delta F) \wedge V / 1 q$ & درگيرى تحصيلى \\
\hline$\cdot / \uparrow \wedge$ & $(q / V Y) Y Y / I r$ & خود كار آمدى \\
\hline$\cdot / 4 \wedge$ & $(9 / V Y) Y \backslash / V V$ & ارزش گذارى درونى \\
\hline.$/ 91$ & $(|\Lambda / r|) F r / q$. & نمره كل ارزيابى شناختى \\
\hline .19 & $(1 Y / \cdot \Lambda) Y \& / 9 \Lambda$ & ساده بودن دانش \\
\hline$\cdot / \Delta \Delta$ & $(11 / \cdot r) r \cdot / \Lambda 1$ & قطعى بودن دانش \\
\hline.$/ 01$ & $(1 \cdot / r \cdot) r q / \Delta r$ & منبع دانش \\
\hline$\cdot / \Delta F$ & $(1 \cdot / 91) \mathrm{MI} / \mathrm{Ar}$ & ذاتى بودن توانايى ياد گيرى \\
\hline$\cdot / \Delta V$ & $(11 / 4 q) r \cdot / r \Delta$ & سريع بودن ياد گيرى \\
\hline $1 / r Y$ & $(Y F / F V) \mid F q / F$. & نمره كل باورهاى معرفتشناختى \\
\hline
\end{tabular}

در اين آزمون هر جه سطح معنادارى به دست آمده بزرگكتر از هـ/ بـ باشد، توزيع دادهها نرمال است. بنابراين مى توان از ضريب همبستخى بيرسون و تحليل ركرسيون استفاده كرد.
براى بررسى نرمال بودن دادهها از آزمون كلمو گروفاسميرنف استفاده شد كه نتايج نشان داد كه مقدار سطح

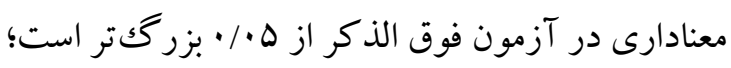
لذا توزيع دادهها منطبق بر توزيع نرمال قلمداد مى گردد.

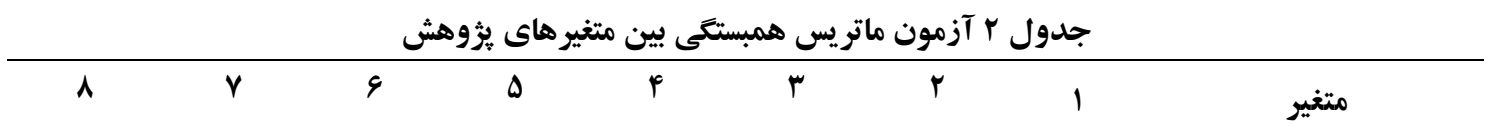




\begin{tabular}{|c|c|c|c|c|c|c|c|c|}
\hline & & & & & & & 1 & 1- در گيرى تحصيلى \\
\hline & & & & & & 1 & 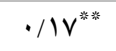 & r- خود كار آمدى \\
\hline & & & & & 1 & $\cdot / V \Delta^{* * * *}$ & $\cdot / 1 f^{* * * *}$ & r- ارزش گذارى درونى \\
\hline & & & & 1 & $\cdot / 9 r^{* * * * *}$ & 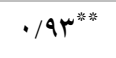 & $\cdot / 1 V^{\text {*** }}$ & F- ارزيابى شناختى \\
\hline & & & 1 & $\cdot 1 \cdot r$ & $\cdot 1 \cdot \Delta$ & $\cdot / \cdots p$ & $\cdot / \cdot V$ & ه- ساده بودن دانش \\
\hline & & 1 & $-\cdot / \cdot \Delta$ & $\cdot 1 \cdot 1$ & $\cdot / \cdot r$ & $\cdot / \cdot 1$ & $\cdot 110^{\text {*** }}$ & 4- قطعى بودن دانش \\
\hline & 1 & $-\cdot / \cdot f$ & $-\cdot \cdot \cdot 1$ & $\cdot / \cdot \wedge$ & $\cdot / \cdot v$ & $.1 \cdot 9$ & $-\cdot 1 \cdot \cdot 9$ & - منبع دانش - V \\
\hline 1 & $\cdot / \cdots 9$ & $-\cdot \cdot \cdot \wedge$ & $\cdot / \cdot r$ & 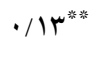 & $\cdot / r^{* * * * *^{*}}$ & $-\cdot / 11^{\text {莎 }}$ & 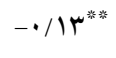 & ^- ذاتى بودن يادگيرى \\
\hline$\cdot / \cdot r$ & $-\cdot 1 \cdot \cdots 9$ & $\cdot / \cdot r$ & $\cdot 1 \cdot 1$ & $\cdot / \cdot \wedge$ & $\cdot / \cdot \wedge$ & $\cdot / \cdot \mathrm{V}$ & $-\cdot / 11^{* * *}$ & 9- سريع بودن ياد گيرى \\
\hline
\end{tabular}

$* \mathrm{p}<\cdot / \cdot \Delta, g^{* * \mathrm{p}<}</ .1$

درگيرى تحصيلى دانشجويان از تحليل رگرسيون جند گانه همزمان يا استاندارد استفاده شد. در رخرى سيون جند گانه استاندارد همه متغيرهاى ييشبين به طور همزمان وارد تحليل مىشوند و هر متغير ييشبين بر اساس توان بيشبينى خودش مورد ارزيابى قرار مى كيرد. نتايج تحليل در جداول ذيل نشان داده شده است.

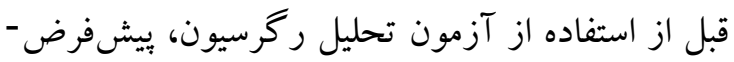
هاى آن از جمله نرمال بودن، همخطى بودن و يكسانى استى

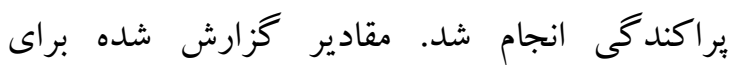
حاكى از آن است كه از VIF, Tolerance مفروضه همخطى تخطى نشده است كه در جدول Fi نشان داده شده؛ اين مفروضه رعايت شده است.
مندرجات جدول r ب نشان ميدهد كه بين

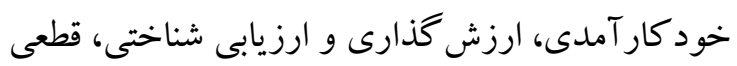
بودن دانش باورهاى معرفتشناختى با دركيرى

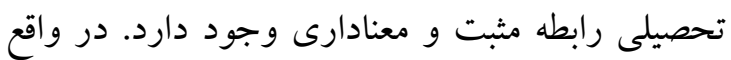
با افزايش خودكارآمدى، ارزش گذارى و و ارزيابى شناختى و قطعى بودن دانش باورهاى معرفتشناختى ميزان دركيرى تحصيلى دانشجويان نيز افزايش مىيابد. همجنين بين ذاتى بودن توانايى يادگيرى و سريع بودن

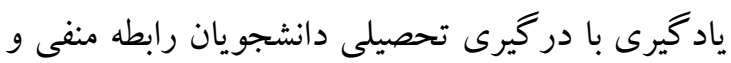
معنادارى وجود دارد. از سويى ساده بودن و منبع دانش با در گيرى تحصيلى رابطهاى مشاهده نشد. براى تعيين نقش هر يكك از متغيرهاى ارزيابىهاى نهيكي شناختى و باورهاى معرفتشناختى در بيشبينى

جدول ץ تحليل واريانس تغييرات متغير ملاكك بر اساس تغييرات متغير هاى بيشيين

\begin{tabular}{|c|c|c|c|c|c|c|c|}
\hline $\mathbf{R}^{2}$ & $\mathbf{R}$ & سطح معنادارى & $\mathbf{F}$ & ميانكين مجذورات & درجه آزادى & مجموع مجذورات & مدل \\
\hline & & & & $r Y F / \cdot \Lambda$ & v & rYGN/GI & ركرسيون \\
\hline$\cdot / 1$ & . &.$/ . \cdot 1$ & $9 / r$. & $\Delta Y / T Q$ & rar & $r \cdot F q 1 / 1 F$ & باقيمانده \\
\hline & & & & & r৭q & rrVYa/vg & كل \\
\hline
\end{tabular}

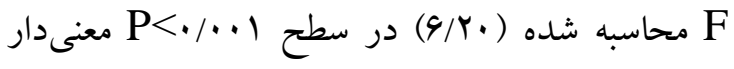
است؛ نشان مىدهد كه همه متغيرهاى بيشبين قادر

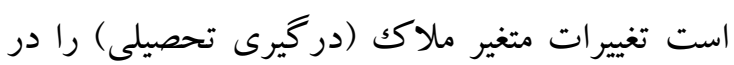
دانشجويان ييشينى كند. در جدول F نقش هر يكك از

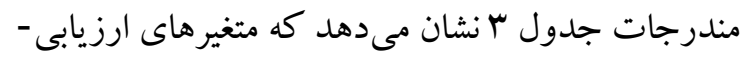

1. هاى شناختى و باورهاى معرفتشناختى، قادرند

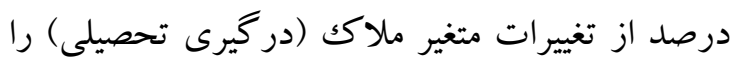
به طور معنىدارى در دانشجويان بيشبينى كنند و جون لهون 
متغيرهاى وارد شده به مدل در بيشبينى درگيرى

جدول f خلاصه نتايج ضرايب ركرسيون براى بيشبينى دركيرى تحصيلى دانشجويان

\begin{tabular}{|c|c|c|c|c|c|c|c|}
\hline \multicolumn{2}{|c|}{ آمارههاى جند همخطى } & \multirow{2}{*}{ معنادارى سطح } & \multirow{2}{*}{$\mathbf{t}$} & \multirow{2}{*}{ ضرايب استاندارد } & \multicolumn{2}{|c|}{ ضرايب غير استاندارد } & \multirow{2}{*}{ مدل } \\
\hline VIF & Tolerance & & & & خطاى استاندارد & B & \\
\hline- & - & $\cdot / \cdots 1$ & $\mathrm{rq} / \mathrm{v}$. & - & $T / \mu r$ & $\Lambda \Delta / \Upsilon^{4}$ & ضر يب ثابت \\
\hline$r / \mu 1$ & $\cdot / A r$ & $\cdot / \cdot 1$ & $r / F$. & $\cdot / 1 V$ & $\cdot / \cdot \Delta$ & $\cdot / 1 r$ & خود كار آمدى \\
\hline T & - /AY & $\cdot 109$ & $\cdot / \Delta r$ & $\cdot / \cdot F$ &.$/ . \Delta$ & $\cdot / \cdot r$ & ارزش گذارى درونى \\
\hline $1 / \cdot 1$ &.$/ 99$ & $\cdot / \cdot 1$ & $1 / \mathrm{VI}$ & $\cdot / \cdot \wedge$ & $\cdot / \cdot r$ & $\cdot / \cdot \Delta$ & ساده بودن دانش \\
\hline $1 / \cdot 1$ & $\cdot / 91$ & $\cdot / \cdots$ & r/A9 & $\cdot / 1 r$ &.$/ \cdot r$ & .1 .9 & قطعى بودن دانش \\
\hline $1 / \cdot 1$ & $\cdot / 91$ & $\cdot / \wedge \Delta$ & $-\cdot / 1 \wedge$ & $-\cdot / \cdots 9$ & $\cdot / \cdot r$ & $-\cdot \cdot \cdot v$ & منبع دانش \\
\hline $1 / \cdot r$ & $\cdot / 9 V$ & $\cdot / \cdots 1$ & $-r / r r$ & $-\cdot / 10$ & $\cdot / \cdot r$ & $-\cdot / 1$ & ذاتى بودن توانايى ياد گيرى \\
\hline $1 / \cdot 9$ &.$/ 99$ & $\cdot / \cdots \wedge$ & $-Y / 94$ & $-\cdot / 1 r$ & $\cdot / \cdot r$ & $-\cdot / \cdot \wedge$ & سريع بودن ياد گيرى \\
\hline
\end{tabular}

يافتهاى بزوهش نشان داد كه بين ارزيابىهاى شناختى (خود كار آمدى و ارزش گذارى درونى) با درگيرى تحصيلى دانشجويان رابطه مثبت و معنادارى وجود دارد. اين يافته با نتايج يزٔوهش هاى دان آقازاده و همكاران

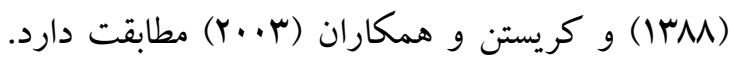
به طورى كه آقازاده و همكاران (1MMN) نشان دادند كه درگيرى شناختى با متغيرهاى

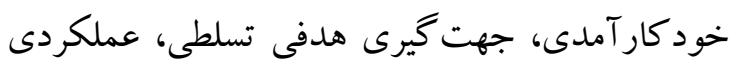
و قطعيت دانش همبستكى مثبت معنادار؛ ولى با جهت گيرى هدفى بيرونى، يادگيرى سريع و توانايى ذاتى

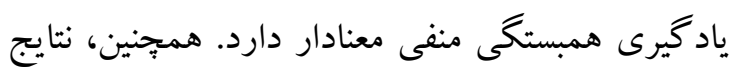
حاكى از آن بود كه بهترين عامل بيشيينى كنندهى

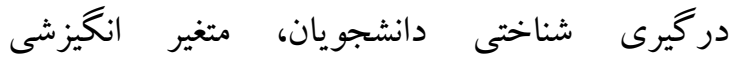
خودكار آمدى است و متغيرهاى جهت گيرى هدفى تسلطى، قطعيت دانش، جنسيت (مؤنث بودن) و توانيى ذاتى ياد گيرى درردههاى بعدى قرار دارند. البته توانايى

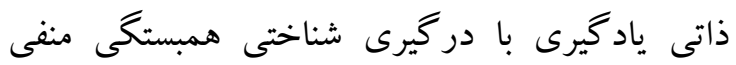

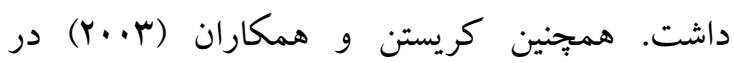

همان طور كه در جدول F نشان داده شده است، متغير خود كار آمدى با ضريب بتاى استاندارد مثبت نيرومندترين متغير در ييشبينى و داراى IV درصد سهم و بس از آن متغير ذاتى بودن توانايى يادكيرى باورهاى دئي

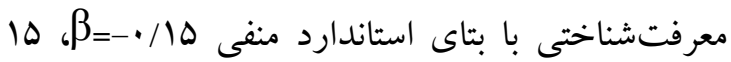
درصد نقش، قطعى بودن دانش با بتاى استاندارد مثبت ץ//•

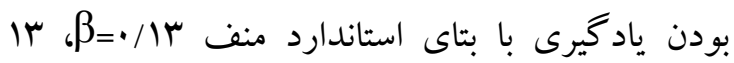
درصد سهم، در تبيين درگيرى تحصيلى در دانشجويان نقش دارند. در واقع متغيرهاى ارزيابى شناختى و باورهاى معرفتشناختى مىتواند درگيرى تحصيلى دانشجويان را بيشبينى كنند. هدف يثزهش حاضر نقش ارزيابىهاى شناختى و باورهاى معرفتشناختى در بيشبينى در گيرى تحصيلى

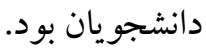


بهترى از خود نشان مىدهند (كريستن و همكاران، ( $($ r.r

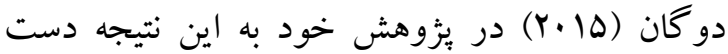
يافتند كه سطوح بالاى خودكارآمدى و بخصوص

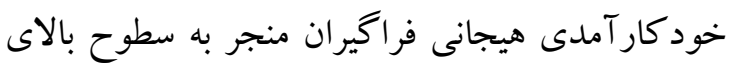

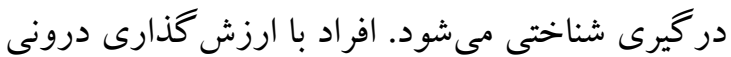
بالا، در مقايسه با افراد با ارزش كذارى يايين، عملكرد

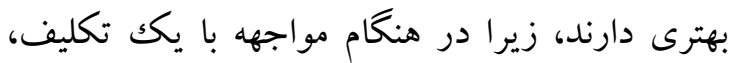
تفكرات متفاوتى دارند، سخت تر كار مى كنند و بشتكار بيشترى نشان مىدهند و اعتقاد دارند مىتوانند از طريق

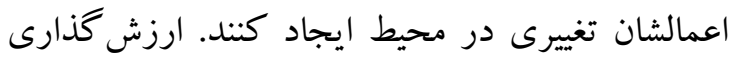
درونى بالا به افراد، قدرت لازم براى انجام تكاليف مشكل و تعهد براى اهداف جالشبرانگيز را مىدهد

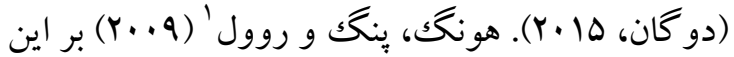
باورند كه در گيرى در موقعيتهاى ياد گيرى سبب مى -

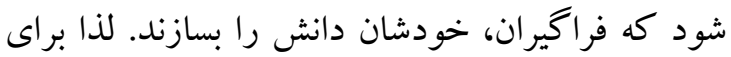
ساخت اين دانش بايد اهدافى را براى خود تنظيم كنند كه در نهايت سبب بهبود و افزايش خودتنظيمى آنان مىشود. به عبارت ديخر، به كارگيرى يادگيرى نه خودتنظيمى و ارزيابى شناختى و درگير شدن دانش آموزان در موقعيتهاى يادگيرى، علاوه بر اينكه موجبات ارتقاى انگيزش آنان رابه تفكر فراهم مى كند، بلكه سبب مىشود كه آنان براى ياد گيرى بهتر، اهدافى

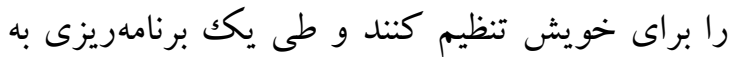
آن اهداف دست يابند. در واقع روش ئسئ ياديرى خودتنظيمى و ارزيابى شناختى از آنجا كه منجر به فعال كردن يادگيرى مىشود و فراخيران در بيى اين هستند كه به اهداف يادگيرى دست يابند، مىتواند منجر به يه ئرد بهبود در گيرى تحصيلى شود. يافته ديخر يزوهش نشان داد كه بين قطعى بودن دانش ديري

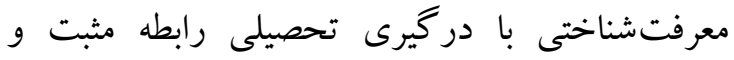

بثزوهشى به اين نتيجه دست يافتند كه بين ارزيابى

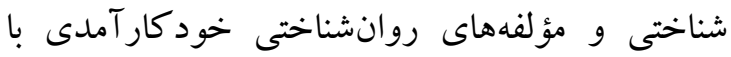
درگيرى تحصيلى رابطهى مستقيم وجود دارد. در واقع

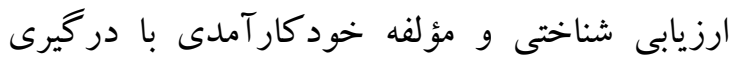
تحصيلى در ارتباط است. از ديدگاه بندورا، خود كارآمدى، باور فرد از توانايى آنياطي خود براى انجام يكك فعاليت خاص، مقابله با موانع و دستيابى به اهداف مطلوب در يكك موقعيت مشخص است. از اين رو، دانشجويانى كه خود كار آمدتر هستند، به احتمال زياد براى دستيابى به نتايج موردنظر خود بيشتر تلاش مى كنند و در رويارويى با جالشهاى بهاى

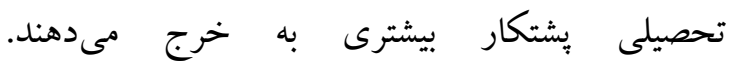

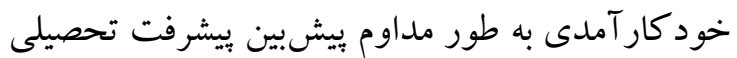

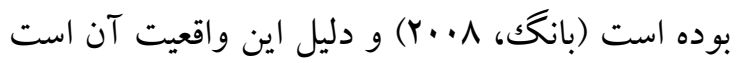
كه با تلاش و يشتكار و در گيرى ارتباط معنادارى دارد. بندورا در نظريه اجتماعى- شناختى خود، برسازه خود كار آمدى و تأثير آن بر يادگيرى تأكيد مى كند؛ زيرا باور افراد از توانايىهاى خود، انتخاب فعاليت و تلاش شخص، درگيرى را در ميان رفتارهاى لازم است براى رسيدن به اهداف، انخيزه و علاقهمندىهاى تحصيلى و رشد شناختى را تحت تأثير قرار مىدهد و و

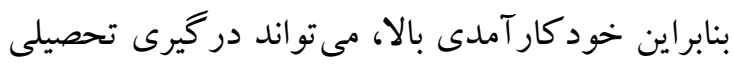

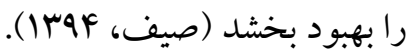
اين يافته نشانگر آن است كه فراگيرانى كه در كلاس

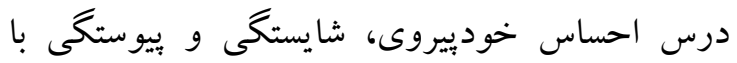
ديخران دارند، نسبت به توانايى خود اطمينان بيشترى خواهند داشت كه همين امر منجر به اين مىشود كه درگيرى تحصيلى بيشتر و در نهايت عملكرد تحصيلى

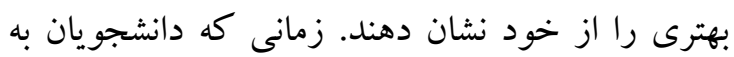
توانايى خود اطمينان داشته باشند، فعاليتهاى تحصيلى را بارزش دانسته و در نتيجه ميزان مشاركت و

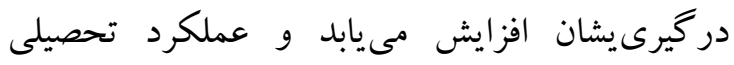


مشاركت بيشتر در ياد گيرى، پِشتكار بالاتر، انخيزش بيشتر و ديخر اهداف مثبت تربيتى مؤثر است (خدابنده اويلى، سبحانىنز اد و مهينىفرهانى، سوبر ا). با توجه به اينكه ذاتى بودن توانايى ياد گيرى به اين معنا

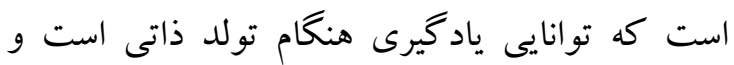
نقش اكتسابى ندارند؛ لذا با درگيرى تحصيلى رابطه

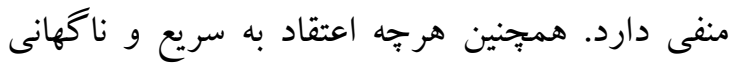
بودن فرايند ياد گيرى قوىتر باشد، بيشرفت و درگيرى هرى تحصيلى كمتر است. هرجه اين باور كه توانايى ياد گيرى بديدهاى ذاتى و تغييرنايذير است، مستحكمتر

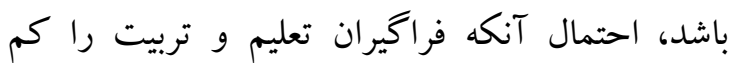
اهميت و بىنتيجه بدانند، بيشتر خواهد بود. همجنين،

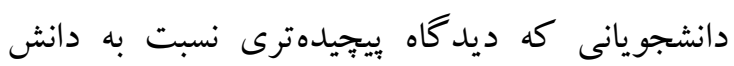
دارند، به احتمال بيشتر اهداف تسلطىترى براى

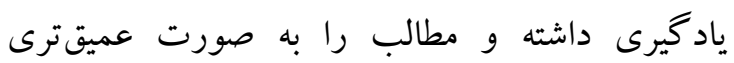
يردازش خواهند كرد (شومر و همكاران، 199V). از سويى نتايج تحليل رگرسيون نشان داد كه متغيرهاى ارزيابىهاى شناختى و باورهاى معرفتشناختى قادرند تغييرات دركيرى تحصيلى را در دانشجويان بيشبينى

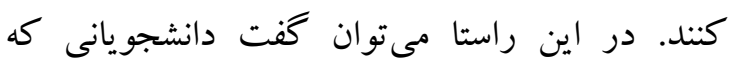
ارزيابىهاى شناختى و ميزان خود كارآمدى و و ارزش كذارى درونى بالايى دارند، بر افزايش شايستخى و جيرگى بر تكليف تمركز دارند و از باورهاى معرفتشناختى رشد يافته ترى بهرهمند هستند و به دانش

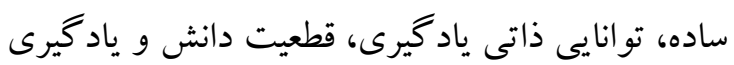

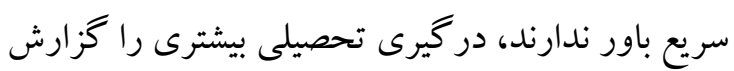
مى كنند. در واقع افراد با ارزيابىهاى شناختى بالاتر و

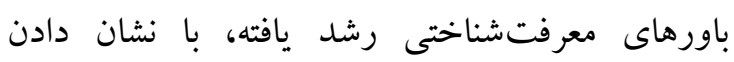

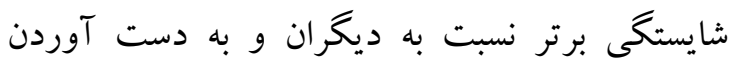

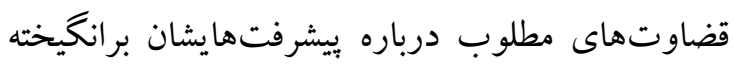
مىشوند، بنابراين دانشجويان با ارزيابى شناختى و و

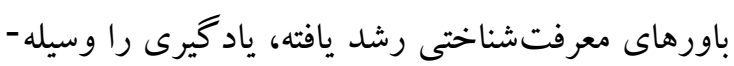

معنادارى وجود دارد. در واقع با افزايش قطعى بودن دانش، ميزان درگيرى تحصيلى دانشجويان نيز افزايش مىيابد. از سويى بين ذاتى بودن توانايى يادگيرى و

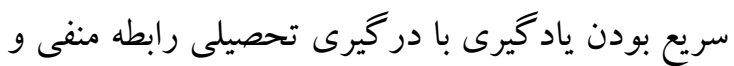
معنادارى وجود دارد. بين ساده بودن دانش و منبع دانش با درگيرى تحصيلى رابطهاى مشاهده نشد. اين

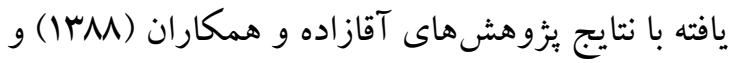
شومر و همكاران (199V) مطابقت دارد. باور به ساده بودن دانش با استراتزىهاى مطالعه دانش آموز و فهم

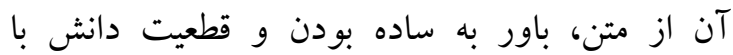
مهارتهاى حل مسئله محتواى با ساختار نامناسب داراى ارتباط است. به طورى كه با توجه به ساده بودن دانش و درگيرى تحصيلى رابطهاى بين آنها مشاهده

نشد. در تبيين اين يافته مىتوان كفت كه اكر دانشجويان دانش را منسجم، بيوسته و بيجيده و به صورت قطعى (يعنى ثبات دانش: مربوط به باورهايى درباره قطعيت دانش و تغيير بذيرى دانش است) در نظر بـيرند، ميزان

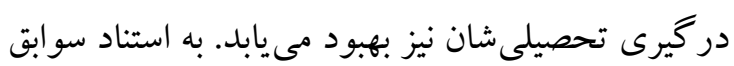
نظرى و يزوهشى باورهاى معرفت شناختى و طرز تلقى

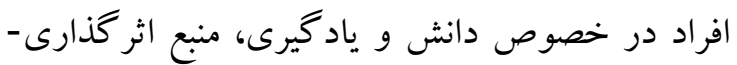
هاى عميق در زندگى تحصيلى و اجتماعى فراگيران است، جرا كه جهت گيرىهاى اساسى آنها را در درباره موضوعات يادگيرى نشان مىدهد. باورهاى معرفت

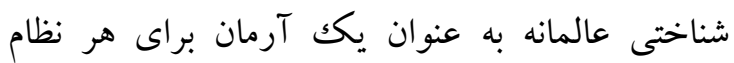

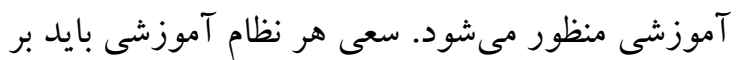
اين باشد كه محيط تربيتى را از عوامل زائد كه القاكننده باورهاى معرفت شناختى ساده انديشانه هستند، بيراسته كند و با عملكرد مناسب در عو امل متعدد دخيل در يادگيرىهاى آشكار و ونهان دانشجويان، باورهاى معرفت شناختى سطح بالا و عالمانه را در آنها سبب لهري شود. جرا كه باورهاى معرفتشناختى عالمانه نيز در 


\section{References}

Aghazadeh SE, Rezaei A, \& Mohammadzadeh A. (2010). Relationship between epistemological and motivational beliefs in students with cognitive engagement. Advances in Cognitive Science, 11(4), 6374. (InPersian)

Akpan ID, \& Umobong ME. (2013). Analysis of Achievement Motivation and Academic Engagement of Students in the Nigerian Classroo. Academic Joumal of Interdisciplinary Studies; 2(3), 385-390.

Akyol Z, \& Gamison DR. (2008). The development of a community of inquiry over time in an online course: Understanding the progression and integration of social, cognitive and teaching presence. Joumal of Asynchronous Leaming Networks, 12(2-3): 3-23.

Berry CA. (1992). Pervious learning experiences strategy beliefs and task definition inselfregulated foreign language learning. Contemporary Educational Psychology, 18, 318-336.

Braten I, \& Stromso HI. (2004). Epistemological beliefs and implicit theories of intelligence as predictors of achievement goals. Contemporary Educational Psychology, 29, 371-388.

Dogan, U. (2015). Student Engagement, Academic Selfefficacy, and Academic achievement goals, and adjustment in middle school. Learning and Instruction, 23, 69-77.

Finlay KA. (2006). Quantifying school engagement: Research report. National center School Engagement; 17, 1-5.

Hong E, Peng Y, \& Rowel L. L. (2009). Homework self- regulation: grade, gender, achievementlevel differences. Learning and Individual Differences, 19(2), 269-276.

Janosz M, Archambault I, Morizot J, \& Pagani L.S. (2008). School engagement trajectories and the their differential predictive relations to
اى براى نمايش قدرت و برترى خود نسبت به ديخران

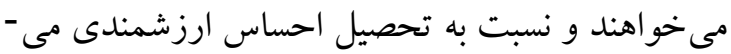
كنند و اين باعث مىشده تكاليف را به نحو مطلوبى انجام داده و در گيرى تحصيلى بيشترى را نشان دهند.

نتيجه كيرى

اين يزوهش با محدوديتهايى مواجه بود. با توجه به

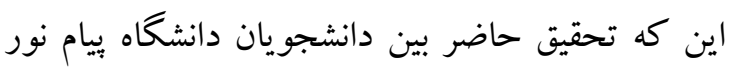

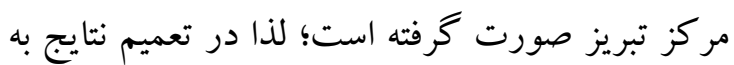
دانشگاههاى ديخر بايد احتياط نمود. از آنجايى كه در

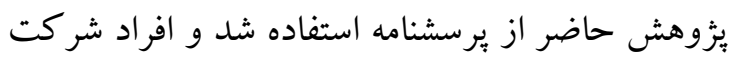
كننده ممكن است نخرشها، عقايد و ديد گاههاى واقعى خود را در برسشنامهها بيان نكنند؛ لذا اين عامل مى تواند تا حدودى نتايج يزوهش را به مخاطره بيندازد.

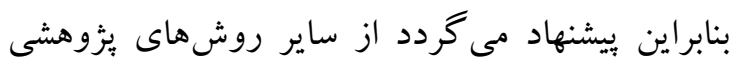
مانند مصاحبه و مشاهده براى جمع آورى دادهها استفاده شود و يافتهاى آن با نتايج يثوهش حاضر مقايسه كردد. آشنايى با راهبردهاى شناختى و فراشناختى و و تأثير و ارتباط اين متغيرها بر درديرى تحهيل تحصيلى دانشجويان، براى مسئولان نظام آموزش عالى امرى ضرورى و بيشبينى آن از اصول بنيادى در برنامه ريزىهاى آموزشى است. با توجه به اينكه عوامل

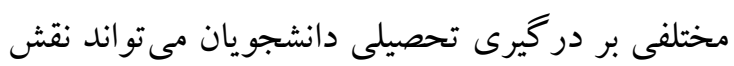
داشته باشد؛ لذا بيشنهاد مىشود كه در يزوهشير إنهاى آتى ويزگ گیىاى شخصيتى استاد، روشهاى آموزشى

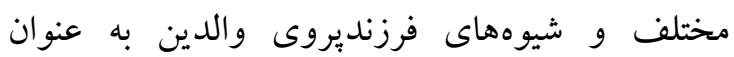
متغيرهاى ميانجى مورد بررسى قرار گيرد.

سياسگزارى نويسند كان از معاونت يُزوهشى دانشگاه بيام نور مركز تبريز و كليه دانشجويان عزيز كه در اجراى برسشنامهها همكارى نمودند، كمال تشكر و قدردانى را دارند. 
dropout. Joumal of social Issues; 64(1), 2140.

Janosz M, Le Blancc M, Boulertice B, \& Tremblay R. E. (2000). Prediciting different types of school dropouts; A Typological approoach with two longitugitudinal samples. Joumal Education Psychology; 92 (1), 171-190.

KhodabandehAvili A, Sobhaninejad M, \& Farmahini Farahani M. (2014). Identification and analysis of epistemological beliefs of Shahed University's students. IRPHE, 20 (1), 79100. (In Persian)

Kirsten C, Carolyn M.T, Wendy M.R, \& Charles H. (2003). Self-efficacy, goal orientation, and fear of failure as predictors of school engagment in high school students. Psychology in the scools; 40(4), 417-427.

Paulsen H, \& Feldman KA. (2005). The conditional and interaction effects of epistemological beliefs on the self-regulated Learning of College Students: Motivational strategies, Research in Higher Education, 7, 731-768.

Pintrich P. R, \& De Groot EV. (1990). Motivational and self-regulated learning components of classroom academic performance. Journal of educational psychology, 82(1), 33-40.

Pintrich P. R. (2000). The role of goal orientation in self-regulated leaming. Cambridge, Massachusetts: Academic Press.

Saefe MH. (2015). A causal relationship model of goal orientations and cognitive engagement: The mediating role of academic emotions and academic self-efficacy. Social Cognition, 4(2), 7-21.

Schommer M. (1990). Effects of beliefs about the nature of knowledge on comprehension. Journal of Educational Psychology, 82, 498504.

Schommer M., Duell O. K \& Hutter R. (2005). Epistemological beliefs, mathematical problem- solving belief, and academic performance of middle school students. The Elementary School Joumal, 105, 289-304.

Seyf AA. (2014). New educational psychology. Tehran: Doran Publications. (In Persian)

Siyami F, Akbari Booreng M, Ayati M, \& Rostaminezhad MA. (2014). The role of students' gender and preferred teaching style in predicting student academic engagement in mashhad University of Medical Sciences. Iranian Journal of Medical Education, 14 (9), 817-826. (In Persian)

Thompson JD. (2006). Organizations in action. New Brunswick, NJ: Transaction Publishers.

Van Uden JM, Ritzen H, \& Pieters J.M. (2014). Engaging students: The role of teacher beliefs and interpersonal teacher behavior in fostering student engagement in vocational education. Teaching and Teacher Education; 37, 21-32.

Wang MT, \& Peck SC. (2013). Adolescent educational success and mental health vary across school engagement profiles. Dev Psychol, 49(7), 1266-76.

Zerang R. (2012). Academic and academic relation among students of Ferdowsi University of Mashhad. Master's Degree in Educational Psychology, Ferdowsi University of Mashhad. (InPersian) 